\title{
Implementation of The Sima'i Method in Improving Memory of Daily Prayers
}

\author{
Ibnu Fiqhan Muslim ${ }^{1}$, Sanudin Ranam ${ }^{2}$, Priyono $^{3}$ \\ 1,2,3 (Universitas Indraprasta PGRI Jakarta, (TB. Simatupang), Jl. Nangka Raya No.58 C, \\ RT.5/RW.5, Tj. Bar., Jagakarsa, Jakarta Selatan) \\ ryo.ahimsa@yahoo.com
}

\begin{abstract}
In religious learning, students are expected to be able to understand the daily prayers taught in class. To achieve these goals, the right method is needed so students can follow these prayers. One way that can be used to prepare daily prayers is the sima'i method. This type of research is classroom action research. The results in this study are students can memorise correctly and both on the accuracy of speech, fluency and attitude. This study concludes that the sima'i method has a positive influence on increasing the ability to memorise daily prayers on the subject. The results are taken based on the comparison of data between before and after being given treatment in the form of applying the sima'i method to the topic.

Dalam pembelajaran agama, siswa diharapkan mampu mamahami doa-doa harian yang diajarkan di kelas. Untuk mencapai tujuan tersebut, diperlukan metode yang tepat agar siswa dapat memahami doa-doa tersebut. Salah satu metode yang dapat digunakan untuk mengajarkan doa-doa harian adalah metode sima'i. Jenis penelitian ini adalah penelitian tindakan kelas. Hasil dalam penelitian ini adalah siswa-siswa dapat menghafal dengan benar dan baik pada ketepatan ucapan, kelancaran dan sikap. Simpulan penelitian ini adalah metode sima' $i$ memberikan pengaruh positif terhadap peningkatan kemampuan menghafal doa-doa harian pada subjek. Hasil tersebut diambil berdasarkan perbandingan data antara sebelum dan sesudah diberikan perlakuan berupa penerapan metode sima'i pada subjek.
\end{abstract}

Keywords: Implementation, Sima'i Method, Memory of Daily Prayer.

Received: May 20, 2019; Revised: June 20, 2019; Accepted: June 28, 2019

\section{INTRODUCTION}

The pre-school period is the golden age where stimulation of all aspects of development plays a vital role in the task of further development, $80 \%$ of children's cognitive development has been achieved at Apriana preschool age (Septiani, Widyaningsih, \& Igomh, 2016: 115) This period is called the developmental stage critical, i.e. the period of the child will be sensitive to stimuli from the environment of Hetherington \& Parke (Azizah, 2015: 18). This time all aspects of the child begin to develop, starting from the physical, cognitive, psychosocial, and developmental languages of Papalia, Olds \& Feldman, (Azizah, 2015: 18). A critical aspect of development during preschool age is cognitive development. 
In improving cognitive students, teachers are required to have the right method in learning, one of which teaches memorization in early childhood. By utilizing the children's memory potential that is still good, the teacher can apply several methods of memorising prayers in early childhood. The development of the child's memory will be fixed when the child is approximately four years old and will reach the best intensity when the child is around 8-12 years old (Afiful Ikhwan, 2017). At that time, memorising power can contain a lot of material, so that it can be said that the memory of children is important to be optimised. (Ahmadi \& Soleh, 2005: 47).

This is in line with the implementation of the 2013 curriculum. In the 2013 curriculum core competencies were applied to students according to their age and level of education (Junaidi, 2016); (Ikhwan, 2018). In preschool-age students are more taught in the competence of social and spiritual attitudes (Umar Sidiq, 2018); (Nurhadi, 2018); (Muhayat, 2018); (Nuraini, 2016). One of the things that can be done is to familiarise students with memorising and understanding daily prayers.

Prayer is a request to God, accompanied by humility to get a good and benefit. In this case, there are those who do not understand the procedures for praying and when the right times to do it correctly, so that prayers can be fulfilled. One must learn to understand prayers and understand the correct times to pray so that prayer becomes a must. Children need to be taught to realize prayers, especially daily prayer from an early age.

One of the foundations that foster pre-school students is the Pelita Hati Jakarta Selatan Foundation. The foundation encourages students so that students have a foundation in character building and religion (Ikhwan, 2014). The Foundation strives to foster characters with various other games and learning. In terms of religion, it also needs the right method in education.

One method that can be used in teaching memorisation is the sima'i method. The sima'i method can be used for children who cannot read or write. Therefore, it is expected that this method can improve the memorisation of the daily prayers of students.

\section{LITERATURE REVIEW}

\section{Memorising}

Memorising is an active effort to be able to enter information into the brain. According to Kuswana (2012: 115) "memorising is getting back the relevant knowledge and stored in long-term memory. Any work if often repeated, must be memorised. "The word memorisation can also be referred to as memory, when studying, it leads us to cognitive psychology, especially in the human model as an information processor.

According to Atkinson (Sa'adulloh, 2008: 46 - 51) said the process of memorising goes through three methods, namely:

a. Encoding (Entering information into memory) Encoding is a process of entering information data into mind. This process, through two tools of the human senses, namely vision and hearing. The two sensory devices, namely the eyes and ears, play an essential role in receiving information as explained in many verses of the Koran, where the mention of eyes and ears is always in tandem. 
b. Storage, Storage is the storage of information that enters the memory warehouse. Memory warehouse is located in long memory (long term memory). All information entered and stored in the memory warehouse will never be lost. What is called forgetting is only we have not been able to recover the information in the memory warehouse.

c. Retrieval (Disclosure) Retrieval is the re-disclosure (reproduction) of information that has been stored in the memory warehouse sometimes and immediately and sometimes needs a lure. If efforts to recall are unsuccessful even though they are provoked, then people call them forgetting and forgetting to refer to our failure to find information in a storehouse of memory, also though he remained there.

Furthermore, according to Solso (Bhinnety, 1995: 74), the human memory system is divided into three parts, namely: first, sensory memory (sensory memory); second, short term memory (short term memory); and third, long-term memory (long term memory). Sensory memory records information or stimuli that enter through one or a combination of the five senses, namely visually through the eye, hearing through the ear odour through the nose, feeling through the tongue and palpation through the skin. If the information or stimulus is not considered, it will be immediately forgotten, but if it is observed, the data is transferred to the short-term memory system. Short memory systems store information or stimuli for \pm 30 seconds, and only about seven chunks of information (chunks) can be maintained and stored in the short-term memory system at a time. After being in the short memory system, the data can be transferred again through a process of rehearsal of training/repetition) to the long-term memory system to be stored, or it can also be lost or forgotten because it is replaced by an additional piece of new information.

\section{Prayer}

Lexical prayer is "calling on God and asking for help and help to him" (Mursalim, 2011: 65). Prayer is a means of communicating between servants and Allah in certain circumstances. The person who gives the prayer means that the person submits a request or plea to Allah about desires, good things, family and property, world affairs, religion and the hereafter. Expect the descent of mercy from God and keep away from all evil.

Prayer is an essential exercise for the soul, must be actively practised in our personal lives. The negligent human soul must be strong enough to cleanse itself once again. Because if the power of prayer is resurrected and used still in human life generally if the soul expresses its purpose clearly and naked, then there is hope that our prayers for a better world will be answered. According to Shiddieqy (2010: 61) "prayer is giving birth to humility and declaring humility and submission to Allah SWT."

As humans, we cannot live alone because each needs other individuals. In Islam, as spiritual beings, we need Allah SWT as a helper in every step. For that, we need to get closer to Him. Praying is obligatory for a Muslim because every Muslim needs his help. As the word of Allah SWT in Surah Al Baqarah verse 186 which means :

"I grant the prayers of those who pray to Me, so let them fulfil My commands, let them believe in Me so that they are always in truth."(QS. A1 Baqarah:186)

Based on the contents of the letter, every Muslim is encouraged to pray every time they start and end routine activities. And if you want your prayers to be pledged by 
Allah SWT, then you must carry out His commands and stay away from His prohibitions.

The purpose and benefits of prayer are

a. Face to God by looking down.

b. I am advancing a request to God, who has an inexhaustible treasury.

c. Obtain the shade of God's grace.

d. Fulfil the obligation to obey and stay away from immorality.

e. Treasury what is needed for steep and narrow times.

f. I am gaining the love of God.

g. Obtain definite results. Because each prayer is well preserved by Allah's side, sometimes the request is fulfilled quickly and sometimes postponed later.

h. Protect yourself from disasters.

i. Refuse disaster or ease the pressure.

j. Become a shield to resist disaster.

$\mathrm{k}$. Refusing to deceive the enemy, eliminate anxiety and produce goals and facilitate difficulties. (Sunarto, 2013: 21)

Daily prayer is a collection of accessible but meaningful prayers in daily work and practice. As taught by the Prophet Muhammad during his lifetime. So, what is meant by habituating daily prayers is to submit a request to God about self-goodness, gratitude, family and property, as well as world and hereafter affairs or asking to avoid a disaster carried out by someone every day before and after starting a job or activity.

Based on the theory the authors conclude that memorising daily prayers is adequately absorbed into the mind of all prayers offered before and after carrying out activities with humility to Allah SWT according to the teachings of Rasulullah Saw.

\section{Sima'i}

Each learning will get maximum results if the tutor has useful competence, uses learning methods that are appropriate to the material, and the use of teaching media needed by students. Therefore, in providing memorised material to pre-school age, children requires a particular method to get maximum learning outcomes.

According to Hafidz (2000: 63), sima'i means to hear. What is meant by this method is to listen to something readings to memorise? This method can be done by looking from the tutor or a recording aid.

Wahid (2014: 137) argues, one method for memorising is not easy to forget is to do sima'n with fellow friends, seniors, or to the teacher from verses that have been memorised. However, if the memoriser is lazy or doesn't follow the rules, then it will cause memorisation to disappear quickly. Also, if the memoriser does not like to do sima'n, then when there is a verse error, it will not be detected. Therefore, multiple doing sima'a. Because, by following a lot of words, it's the same as repeating the previous or new memorisation. 
This method can be applied to memorisers of any age, especially those who have a good memory. For preschool-aged children who have limited reading, the sima'i way helps them memorise by listening to the daily recitation of prayer.

It can be concluded that the application of the Sima's method has two types, first listening to be memorised, the two listenings with the aim to facilitate and maintain memorisation.

\section{METHOD}

The research method used in this study is Classroom Action Research (CAR). The nature of classroom action research is a variety of classroom contextual learning research carried out by teachers to solve learning problems faced by teachers, improve quality and learning outcomes and try new things in learning for quality improvement and learning outcomes.

\section{RESULT AND DISCUSSION}

At the first meeting, the researcher carried out observations in the school, interviewed the leaders and teaching staff in the school and conveyed the objectives and plans of the activity. The researcher pre-tests the students about memorising daily prayers. At the next meeting, the researchers conducted class introductions and mastery, introduced the sima'i method, applied the sima'i method, and carried out rote tests to students. At the third meeting, researchers evaluated learning and corrected weaknesses / obstacles experienced by students.

Introducing the Sima's method in early age students does not experience problems. Learning to old age students is more comfortable when invited to listen or follow directions. When the researcher gives sima'i material in the form of daily prayers, students attend. In this method, the students' memory and focus are superior. Students who have good memory and attention will be able to memorize daily prayers using the sima'i method easily. After being given the sima'i way, the researcher tests the memorisation results by asking students to progress one by one. Every student who advances to memorise previously guided using the sima'i method.

In 3 meetings, the researcher applied the sima'i method for prayer learning before going to bed, waking up, praying for both parents, and praying before eating. Based on the results obtained from the study, it will be made into three cycles that have been made on average for the four daily prayers.

Cycle I points of speech accuracy indicate the number 30 of the total scores of 50, the aspects of fluency show the amount 20 from the total points of 35, and the locations of adab / attitude show 5 points out of a total of 15 points. The final score is 55 .

The second cycle of points of speech accuracy shows the number 40 of the total scores of 50, the aspects of fluency show the amount 25 from the total points of 35 , and the locations of adab / attitude show 10 points from a total of 15 points. The final score is 75 .

The third cycle of points of speech accuracy shows the number 45 of the total scores of 50 , the aspects of fluency show the amount 30 from the total points of 35 , and the 
locations of adab / attitude show 15 points from a total of 15 points. The final score is 90 .

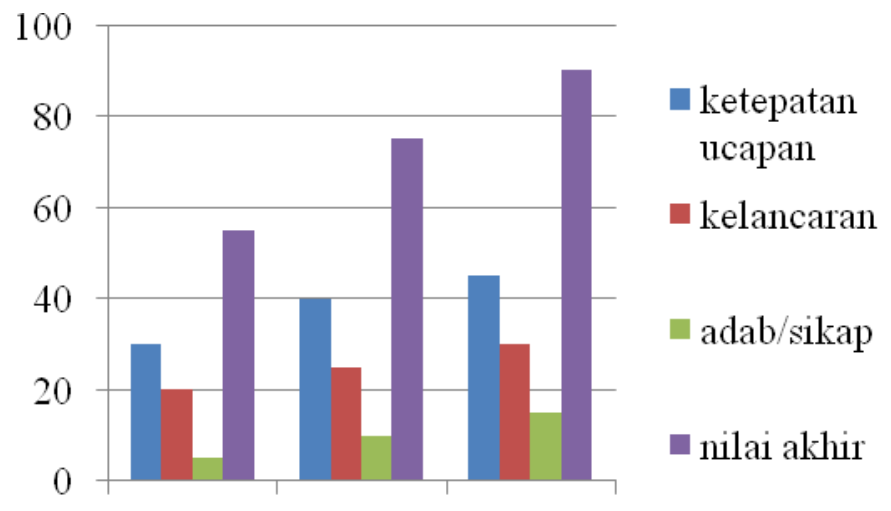

Siklus 1 Siklus 2 Siklus 3

Picture 1. Cycle diagram for applying the sima'i method

Based on the three cycles described above, it can be seen that the sima'i method has a positive impact on students to help them memorise. The results continue to increase until the last cycle. Students can memorise well the reading of daily prayers. Based on the accuracy of speech, fluency, and their attitude when saying daily prayers memorizing daily prayers using Arabic, so it requires precision speech. With the Sima'i method, they replicate the way the pronunciation is taught by the researcher; this can help early students who have not read fluently in Arabic. Smooth memorisation with the sima'i method is assisted by the researcher by giving pressure and pauses at the right time so that students can quickly receive pieces of prayers into a substantial sentence of worship.

The effect of the Sima'i method on student attitudes when the rote test is to make students feel confident because students feel more confident in the accuracy of their speech. If students feel confident, they will provide improvements to the other attitudes in memorization. For example, with confidence, students will become more calm and relaxed during the test. This condition can control students' attitudes and focus on memorisation.

The results of memorising these daily prayers are the results of memorised tests in the form of memorandum deposits. Each student advances one by one to the front of the class, facing the researcher then reads the memorisation of his prayer. The researcher listens to the memorisation of the students and pays attention to the way they are pronounced. Students are enthusiastic about memorising with the Sima'i method because it is considered fun. This is a motivation for the instructors at Preschool Pelita Hati to apply the Sima'i method to memorising material.

From the results of the evaluation in the form of memorisation tests using the memorisation method of Sima'i which was carried out by all students, what was done on the last day of the meeting showed that students could memorise correctly and well on the accuracy of speech, fluency and attitude. 


\section{CONCLUSION}

Based on the results of the study, it can be concluded that the application of the Sima'i method can improve the memorisation of the daily prayers of Preschool Pelita Hati students. This can be seen in each learning cycle in the results of the study. Based on the results of the research that has been done and analysed, the subject experienced an increase in the ability to memorise at the prayer before eating, a prayer for both parents, a prayer before going to bed, and a prayer to wake up.

The increase in each prayer that is quite diverse is influenced by the complexity of each prayer that is quite diverse as well. Therefore researchers always strive to minimise the inhibition of the research process by making various approaches to the subject. This study concludes that Sima'i's method had a positive influence on increased ability to memorise daily prayers on the subject. The results are taken based on a comparison of data between before and after being given treatment in the form of applying the sima'i method to the topic.

\section{REFERENCES}

[1] Azizah, N. (2015). Kemampuan Theory of Mind Anak Usia 3-5 Tahun Ditinjau dari Intensitas Interaksi dengan Saudara Kandung. Jurnal Psikologi Tabularasa, 10(1), 18-30.

[2] Bhinnety, M. (1995). Struktur dan Proses Memori. Buletin Psikologi, 16(2), 74 88.

[3] Mursalim. (2011). Doa dalam Perpsektif Alquran. Jurnal Al-Ulum, 11(1), 63 - 78.

[4] Septiani, R., Widyaningsih, S., \& Igomh, M. K. (2016). Tingkat Perkembangan Anak Pra Sekolah 3 -5 Tahun yang Mengikuti dan Tidak Mengikuti Pendidikan Anak Usia Dini. Jurnal Keperawatan, Volume 4(22), 114 - 125

[5] Ahmadi, A., \& Soleh, M. (2005). Psikologi Perembangan. Jakarta: PT Rineka Cipta.

[6] Bungin, B. (2013), Metode Penelitian Sosial dan Ekonomi. Jakarta: Kencana.

[7] Hafidz, A. A. (2000). Bimbingan Praktis Menghafal Alquran. Jakarta: Bumi Aksara.

[8] Hamidi. (2005). Metode Penelitian Kualitatif. Malang: UMM Pres.

[9] Kuswana, W. S. (2012). Taksonomi Kognitif Perkembangan Ragam Berpikir. Bandung: PT Remaja Rosdakarya.

[10] Mardalis, (2006). Metode Penelitian Suatu Pendekatan Populasi. Jakarta: Bumi Aksara.

[11] Morissan. (2012). Metode Penelitian Survei. Jakarta: Kencana.

[12] Rauf, A. A. (2004). Kiat Sukses Menjadi Hafizh Qur'an Da'iyah. Bandung: PT. Syaamil Cipta Media.

[13] Shiddieqy, H. A. (2010). Pedoman Dzikir \& Doa. Semarang: PT. Pustaka Rizki

[14] Sa'adulloh. (2008). 9 Cara Praktis Menghafal Alquran,. Jakarta: Gema Insani.

[15] Sunarto, A. (2013). Doa Bersumber dari Alquran dan Alhadist. Jakarta: Bintang Terang.

[16] Wahid, W. A. (2014). Cara Cepat Bisa Menghafal Alquran. Yogyakarta: Diva Press.

[17] Afiful Ikhwan. (2017). Development Of Quality Management Islamic Education In Islamic Boarding School (Case Study Madrasah Aliyah Ash Sholihin). AlHayat: Journal of Islamic Education, 01(01), 1-27. 
[18] Ikhwan, A. (2014). Integrasi Pendidikan Islami (Nilai-Nilai Islami dalam Pembelajaran). Ta'allum: Jurnal Pendidikan Islam, 2(2), 184. https://doi.org/10.21274/taalum.2014.2.2.179-194

[19] Ikhwan, A. (2018). Management of Learning Assesment Using Curriculum 2013 (Case Study in Islamic Primary School (MI) Muhammadiyah 5 Wonoasri Ponorogo - East Java - Indonesia). MUADDIB: Studi Kependidikan Dan Keislaman, 08(02), 108-123. https://doi.org/10.24269/muaddib.v8i2.1422

[20] Junaidi, K. (2016). Sistem Pendidikan Pondok Pesantren di Indonesia (Suatu Kajian Sistem Kurikulum di Pondok Pesantren Lirboyo). Istawa: Jurnal Pendidikan Islam, 2(1), 95-110. https://doi.org/10.24269/ijpi.v2i1.364

[21] Muhayat, I. (2018). Accreditation Policy and Quality of Higher Education. AlHayat: Journal of Islamic Education, 02(01), 1-16.

[22] Nuraini, M. F. M. (2016). IMPLEMENTASI KURIKULUM 2013 PADA MATA PELAJARAN PENDIDIKAN AGAMA ISLAM DI SD MUHAMMADIYAH TERPADU PONOROGO. Istawa: Jurnal Pendidikan Islam, 1(2), 52-80. https://doi.org/10.24269/ijpi.v1i2.167

[23] Nurhadi. (2018). Manajemen Penilaian Pembelajaran Menggunakan K13. AlHayat: Journal of Islamic Education, 02(01), 1-16.

[24] Umar Sidiq, L. I. (2018). Inclusive Curriculum Education Modification Management (Case Study at Ponorogo National Immersion Primary School). AlHayat: Journal of Islamic Education, 02(02), 1-11. 